Chyrkov O. "To Hollywood from Ukraine" by Stanislav Suknenko...

\title{
“TO HOLLYWOOD FROM UKRAINE” BY STANISLAV SUKNENKO, WITH INTERVIEWS BY YANA KRASNIKOVA (2018, Kyiv: SAMIT-BOOK, 360 p.): A BOOK ON CITIZENS FROM UKRAINE IN THE US CINEMATOGRAPHY
}

Los Angeles's famous Hollywood, thanks to the concentration of film makers who made a major contribution to the world cinema, even in the first half of the twentieth century became known in different parts of our planet. Today, it does not contain most of the American film industry; however, its name often relates to the entire film production of the country. At the end of the summer and autumn of 2018, the publishing house SAMIT-BOOK introduced in Ukraine a new book "To Hollywood from Ukraine" (in English). It tells about descendants from Ukraine of different ethnic backgrounds, as well as their successors, who became globally famous due to their achievements in the field of the influential American cinema.

The project was supported by the Ministry of Information Policy of Ukraine. It should be noted that the publication of the book took place in the period when significant positive changes in film production and television started in Ukraine. It is indicative that the share of Ukrainian cinema and TV products has increased. The author of the book, movie expert Stanislav Suknenko, used a variety of print media and electronic information resources (it would be nice to have listed them), as well as interviews done by Miss Universe Ukraine 2017 Yana Krasnikova with a number of representatives of the modern fellow countrymen involved in the US movie industry. The editor of the publication is Philip Sutcliffe. The book contains a large number of illustrations provided by Global Images Ukraine (Sales Director Kiril Matvienko). This agency is the exclusive representative of Getty Images - the world leader in the visual communications market (unfortunately, the Ukrainian representative of this powerful company has a Russian-language web page and does not have a Ukrainian one).

The book consists of 36 chapters, most of which cover the life and career of one person in the American film industry at a time: a director, scriptwriter, operator, artist, composer, singer, actor, etc. - all of them having at least a Ukrainian descent. But there are sections where groups of such persons are united. In general, destinies of about a hundred people from Ukrainian lands (ethnic Ukrainians, Jews, Russians, individuals of the mixed ethnic origin) are reflected. Some facts of their biographies, professional and sometimes social activity, which show the connection with Ukraine, characterize their career and contribution to the development of the cinema in the USA at various stages of its history. For example, the first chapter "In the beginning was... Hollywoodland" tells about the life of Lewis J. Selznick (born Laizer Zeleznik in 1870 in Kyiv), Myron Selznick, David O. Selznic, Louis B. Mayer (born Lazar Meir in 1884 in Dymer, near Kyiv), while the last section, "To Hollywood from Ukraine Today: Actors" highlights the work of wellknown contemporary actors, such as Milla 
Jovovich, Vera Farmiga, Olga Kurylenko, Mila Kunis, Katheryn Winnick. The life and career of certain persons are explained in more detail. The author states that some previously known dates and facts from the biographies of the personalities presented in the book have been clarified or corrected. A lot of new information has been obtained from an interview given by seven figures of the American film industry. The merit of the author is the outline and a certain systematization of a wide range of Ukrainerelated, at least by origin, successful participants of the US film industry, which can be further refined and supplemented.

In our opinion, it is an exaggeration to call all the persons represented in the book our "compatriots". It would be quite problematic to generally identify these people (as well as other people from Ukraine and their descendants) in the context of their relation to Ukraine. In this regard, there is no established concept today. Among them there are real compatriots, but there are also grandchildren of people born in the nineteenth century in the territory that now belongs to Ukraine. Certain individuals among those highlighted in the book are aware of their Ukrainian background since childhood, do not conceal it, and preserve it as they can. But the connection with the Ukrainian culture, Ukrainian state, economy, or politics of many well-known figures of the American cinema in the past and today is too weak. In many cases, it was deliberately not advertized or did not prove to exist. In the past, there were time periods when not only the citizens of the USSR feared to confess the existence of their foreign relatives; after all, the careers of US citizens could also suffer because of their links with the communist USSR.

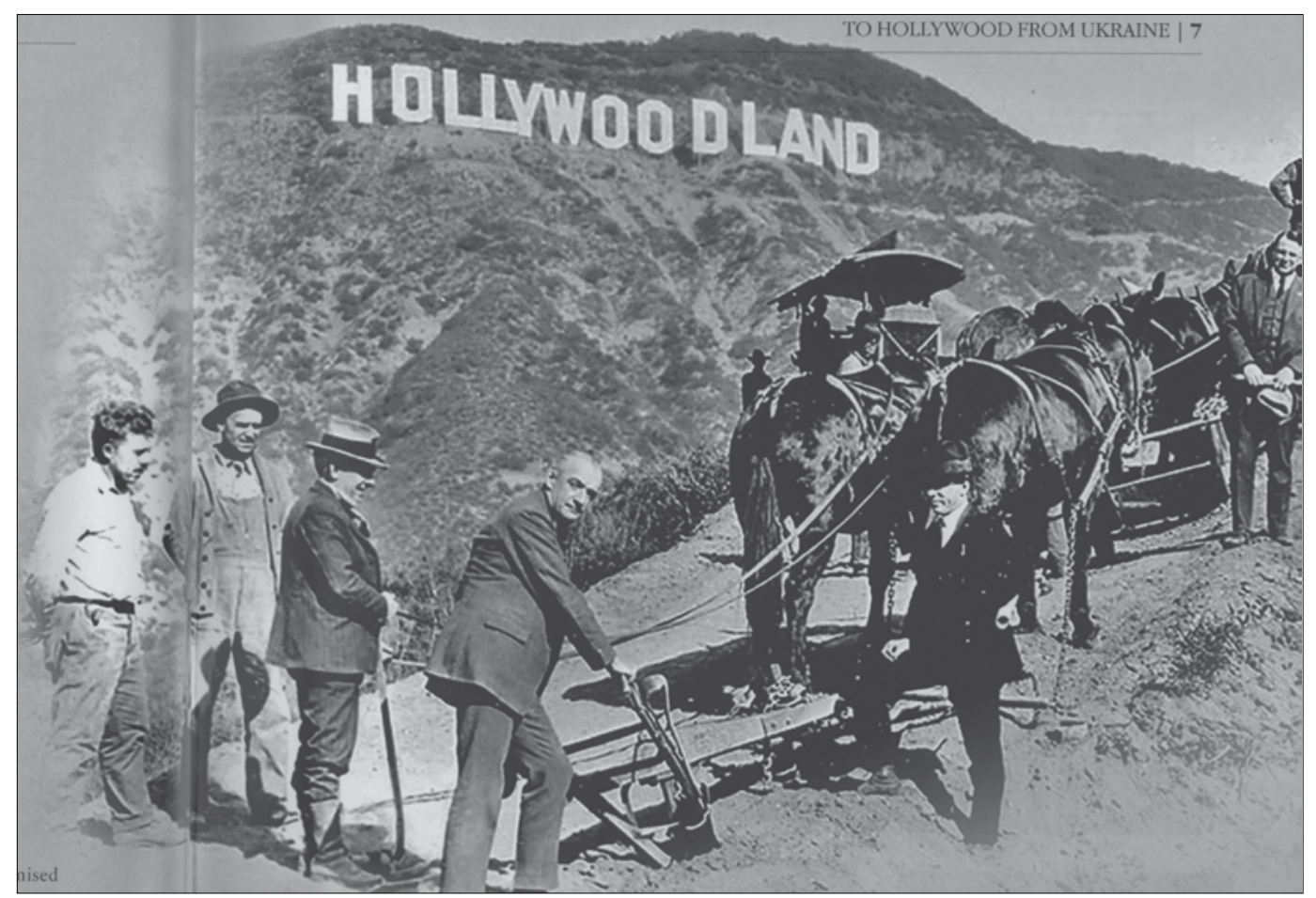

An illustration from the book 
In our opinion, this literary and artistic Ukrainian-language publication will create a positive image of our society provided that it is accessible to the English reader. The book was presented at the Museum of Kyiv History, at the Odesa International Film Festival (2018), at the International Book Publishers' Forum in Lviv, etc.

The book will be soon published on web resources, and will subsequently become available in the Ukrainian language. In this case, it will open a lot of new pages for the mass Ukrainian reader, will help overcome the complex of inferiority, strengthen national self-esteem, establish new ties between modern Ukrainian society and descendants from Ukraine.

Stanislav Suknenko informed attendees of the presentation that "To Hollywood from Ukraine" would be screened as a documentary, which will open an unknown part of the history of Ukrainians abroad to the Ukrainian audience. The author of the book continues working in this direction, collecting material for the second volume. So, the study will be continued.

Oleh CHYRKOV orcid.org/0000-0001-8888-0126 research fellow of the Ukrainian Ethnology Department of RIUS

\section{ПРЕЗЕНТАЦІЯ КОЛЕКТИВНОӦ МОНОГРАФЇ̈ «УКРАЇНА Й УКРАЇНСТВО В ЕТНОКУЛЬТУРНИХ ПРОЦЕСАХ: КОНЦЕПТУАЛЬНІ УЗАГАЛЬНЕННЯ»}

У квітні 2018 року вийшла друком колективна монографія «Україна й українство в етнокультурних процесах: концептуальні узагальнення» (Київ: НДІУ, 2018. 304 с.). Її авторами є як знані, так і молоді у науковому середовищі дослідники: В. Баран, С. Бойко, О. Гула, Л. Залізняк, С. Наливайко, Л. Отрошко, Т. Присяжна, Ю. Фігурний, О. Чирков, О. Шакурова, М. Шостак.

Дещо згодом, 17 травня 2018 р., у рамках участі НДІУ у Всеукраїнському фестивалі науки відбулася іiі презентація. Модератором наукового заходу став заступник директора НДІУ МОН України В. Терлецький, який наголосив, що ця праця здійснена у відділі української етнології у форматі виконання науководослідної роботи, завершеної минулого року, та надав слово завідувачу відділу Ю. Фігурному.

У своєму виступі вчений-українознавець відзначив, що монографія, яка нині презентується, - це не тільки доробок виключно відділу української етнології. Це підсумок багаторічної праці творчого колективу під керівництвом доктора історичних наук, професора, члена-кореспондента НАН України В. Барана 3 виконання науково-дослідної роботи «Україна й українство в етнокультурних процесах світу» (2015-2017). Її виконавцями у різні роки були наукові співробітники НДІУ: О. Гула, Л. Залізняк, 